\title{
Analysis of pedagogical communication and interaction of lessons with tablet application
}

\author{
Martina Maněnová ${ }^{1 \mathrm{a}}$ \\ ${ }^{1}$ Enstitute of Primary and Preprimary Education, Faculty of Education, University of Hradec Kralove \\ Rokitanskeho 62, 50003 Hradec Kralove; Czech Republic
}

\begin{abstract}
The article describes possibilities of lessons evaluation by means of structured observations. Our study took an interest in the use of information and communication technologies in teaching of mathematics on elementary school. Concrete it was case tablets implementation in standard lessons on elementary school. The aim of the submitted project was to find out if tablets application in lessons would influence pedagogical communication and interaction. We selected structured FIAS (Flanders Interaction Analysis system) observation as a basic research method. This method was spread on 16 categories in total, which we used for structured observation of lessons. The results were successively processed to interaction characteristics.
\end{abstract}

\section{Introduction}

Educational process reflects the development of information and communication technologies. Information and communication technologies (ICT) became one of the components of education and their position and implementation are followed by state institutions on the one hand and are the object of research of professional workers on the other hand. The extensive international investigations exist, [3 and 4], SIES, STEPS, which are aimed at the problems of ICT implementation to education (especially on primary schools). We can compare on the basis of information from these investigations in separate countries not only from the viewpoint of school equipment, but also didactic exploitation of technologies is also a part of some investigations.

\subsection{Tablets in Education}

ICT implementation was firstly realized in the form of computer classrooms. Computer classrooms were gradually formed in schools (e.g. INDOŠ project in the Czech Republic 2001-2006). Lately the schools were furnished with interactive boards and notebook or

\footnotetext{
${ }^{a}$ Corresponding author: martina.manenova@uhk.cz
} 
mobile classrooms, chiefly thanks to the projects from European social funds. Tablets in teaching become the trend of present time.

Growing interest in tablets is clarified even by the results of the newest of the Czech school inspection which found out that entire majority of primary schools $(93.5 \%)$ feel necessity of the highest connection of modern technologies in teaching. About $14.4 \%$ of Czech primary schools and $16.4 \%$ of secondary schools have certain experience with tablets at present [5].

In 2012 a study Tablets in education [7] was published, where separate technologies from the viewpoint of three selected criteria were evaluated (Tab. 1). Evaluation A corresponds best with educational aims.

Table 1.Study Tablets in education (Marés, 2012).

\begin{tabular}{lccc}
\hline & PC & Netbook & Tablet \\
\hline Motivation & C & B & A \\
Digital literacy & A & B & C \\
Cross-cutting skills and superior order & C & B & A \\
cognitive skills (communication, & & & \\
collaboration, independent learning & & & \\
and team work) & & & \\
\hline
\end{tabular}

\section{The Project}

The aim of the project was to follow educational process and evaluate pedagogical communication and interaction in the frame of teaching unit, in which the tablets were applied.

Quantitative design of research with standardised observation as a basic research method was selected for reaching the research aim. We choose the method of interactive analysis for standard observation where it was a case of observation and evaluation of communication and interaction in class. We selected Flander's system of interaction analysis from the accessible observation systems [2]. We gave priority to it before observation system by A. A. Bellacj, whose symbolic sign language quite exactly records separate actions which take place in the class including teacher's and pupil's activities but is rather complicated. The observer has to follow and record all the time 54 categories which originated from splitting of the individual categories, describing activities which run through in educational process [3].

Flanderś interaction approach came out for the conception that teaching is formed by successions of interaction acts which repeat both from teacher's side and even pupil's side and their mutual part in the course of teaching tells us about its characteristic. The word "acts" could be replaced by the concept categories of behavior and successively these categories transfer to concrete activities which enable us to follow and determine them unequivocally [10]. Flander's system was expanded to a total of 16 categories:

\section{Teacher}

U1 - accepts pupil's feelings and behavior, tries to show sympathy in a constructive way;

U2 - values pupil positively, expresses favorable opinion of work, answers, actions, characteristics or behavior, is encouraging, makes jokes, generally values achievement;

U3 - uses, elucidates, develops, or accepts what pupil suggests, repeats pupil's statements in order to stress their value so others can remember them, paraphrases or modifies answers or comments on the task;

U4 - asks questions (non-rhetorical), stimulates pupil; 
U5 - explains, tells, gives lecture, introduces own opinion;

U6 - gives directives or instructions, organizes;

U7 - 7. Criticises, enforces authority, tries to change pupil's unsuitable behaviour or actions.

\section{Pupil}

Z1 - asks questions, seeks help and support from teacher;

Z2 - asks questions, seeks help and support from other pupils;

Z3 - states, explains and introduces own opinions when pressured or influenced by teacher, answers when called on to do so rather than raising hand first;

Z4 - states, explains and introduces own opinions arising from own actions or motivation, raising hand when answering questions or spontaneously referring to own experience or opinion;

Z5 - directs or modifies actions of others, offers them help (we include here any presentation by the pupil, such as use of the blackboard when 'teaching' other pupils);

Z6 - communicates with other pupils during a team activity;

Z7 - participates in whole class discussion;

Z8 - pursues individual learning activity without visible interaction;

$\mathrm{O} 1$ - is silent or confused, stops working, communicates indistinctly.

On the basis of the obtained characteristics of individual teaching lessons we selected for further description of the level of communication and interaction grouping of separate activities of teacher and pupils to activity bunches which formed after processing individual indexes [10]:

$I i=\frac{A z}{A u}$

where:

Ii - overall index of interaction,

$\mathrm{Az}-$ index of pupils activity $(\mathrm{Zo}+\mathrm{Za}+\mathrm{Zp})$,

$\mathrm{Au}-$ index of teacher's activity $(\mathrm{Ua}+\mathrm{Uv}+\mathrm{Ur})$,

$\mathrm{K}$ - total number coding - categories $\mathrm{O}$,

Zo - index search of pupil's support, items $(Z 1+Z 2) / K$,

$\mathrm{Za}-$ index of pupil's activity, items $(\mathrm{Z} 3+\mathrm{Z} 4+\mathrm{Z} 8) / \mathrm{K}$,

$\mathrm{Zp}$ - index enforcement pupil in the classroom, items $(\mathrm{Z} 5+\mathrm{Z} 6+\mathrm{Z} 7) / \mathrm{K}$,

$\mathrm{Ua}$ - index teacher's acceptance of student entries, items $(\mathrm{U} 1+\mathrm{U} 2+\mathrm{U} 3) / \mathrm{K}$,

$\mathrm{Uv}$ - index teacher's teaching activities, items (U4+U5)/K,

$\mathrm{Ur}$ - index teacher's class management, items $(\mathrm{U} 6+\mathrm{U} 7) / \mathrm{K}$.

Observations were realized in a total of ten lessons. Tablet (tablet nests) was used in five lessons, in the remaining five teaching was carried out without tablets. Other technologies were not included in any lesson. It was a case of lessons of science in the third class of primary school. The pupils worked in all five lessons with tablet of Android operation system. Video Records were obtained from teaching and successively were coded by the Code Net programme, which was developed at the Faculty of Education, University Hradec Králové and operated as a web application. It enabled to record lessons unit after time intervals (in this research the time interval was $3 \mathrm{~s}$ ), when the prevailing activity in the lesson is recorded (see above the separate activity categories). The obtained data were processed by statistical programme NCS2007 and programme MS Excel, Code Net programme. The tests of normality were applied for testing (Skewness, Omnibus, Kurtosis). 
The tests did not prove unambiguously normal spreading of data therefore even nonparametric tests were further used.

\section{Result of research}

Ten lessons in total were analyzed. Absolute frequencies of individual activity categories were determined in each lesson, then followed calculating of partial indexes and total indexes of interaction. The mean values of activity categories for experimental lessons (lesson with tablets) and the control lessons (teaching without tablets) are demonstrated in Fig.1.

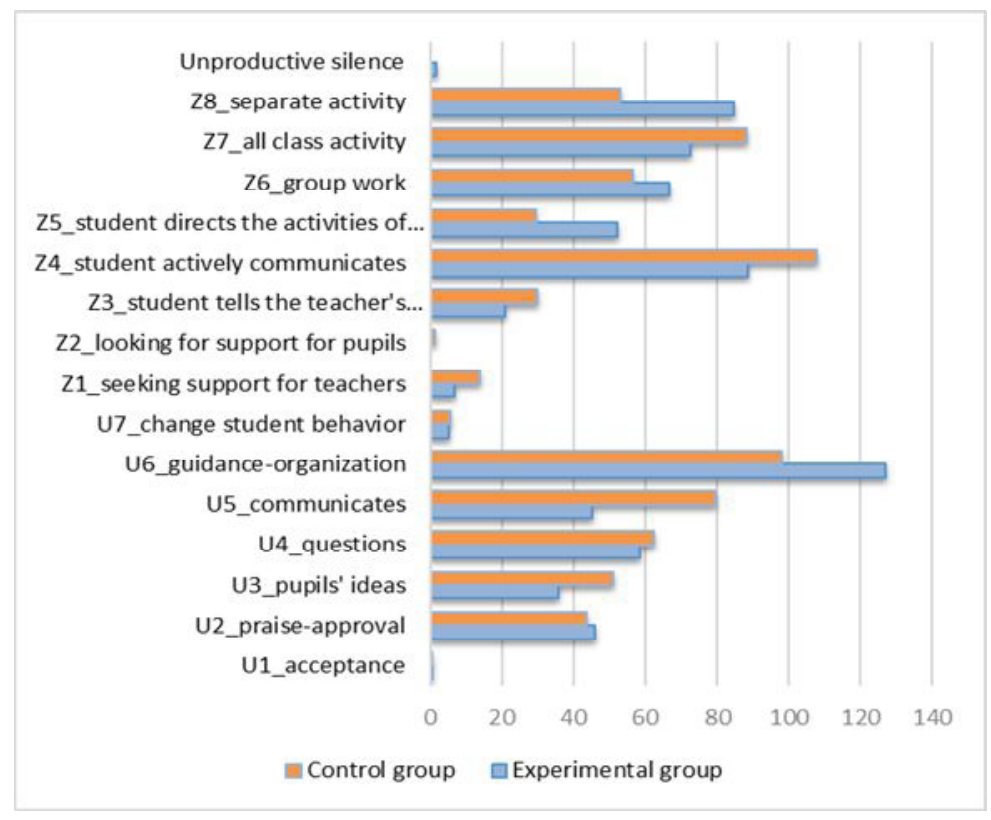

Fig.1 The mean values of separate activity categories in experimental and control lessons

We can observe from the graph that in the experimental teaching prevails mostly category U6 (the teacher - explains, informs, introduces own opinion, acquaints pupil with own attitudes and values, elucidates or glosses subject matter (we include the use of video and sound recordings here, as it is the teacher who selects them), that corresponds with directing the work with tablet. Further in the experimental teaching category Z8 outbalances (the pupil pursues individual learning activity without visible interaction)

In the control teaching prevails category U5 (the teacher asks questions about the task, method of working or organization, expects answers rather than asking rhetorical questions, uses questions to stimulate pupil), Z4 (the pupil states, explains and introduces own opinions arising from own actions or motivation, raising hand when answering questions or spontaneously referring to own experience or opinion) and discussion of the whole class is taking place.

Descriptive characteristics of the mean indexes of interaction are given in Table 2. 
Table 2. Descriptive characteristics

\begin{tabular}{lccccccc}
\hline Index of Interaction & Mean & $\begin{array}{c}\text { Standard } \\
\text { deviation }\end{array}$ & Minimum & Maximum & Range & Median & Modus \\
\hline Experimental group & 1,251 & 0,174 & 1,058 & 1,383 & 0,325 & 1,375 & - \\
Control group & 1,130 & 0,189 & 0,923 & 1,367 & 0,444 & 1,033 & 1,033 \\
\hline
\end{tabular}

We determined null hypothesis Ho for the comparison of the mean values of the indexes of interaction in the control an experimental teaching and tested it by Student's t-test and Mann-Whitney nonparametric test (Tab.3).

Ho: We do not suppose statistically important difference between the mean values of interaction index in the control and experimental group.

Table 3. Results of Student's t-test and the Mann-Whitney test

\begin{tabular}{lccc}
\hline Index of interaction & T value & Z value & Decision \\
\hline Experimental group & 1,0605 & 1,6762 & ${\text { Accept } \mathrm{H}_{0}}$ \\
Control group & & & \\
\hline
\end{tabular}

Considering the fact that the level of importance was determined $\alpha=0,05$ and critical value $\mathrm{tkr}=2,306$ for testing, the null hypothesis was accepted. Statistically important difference was not proved between the mean values of index of interaction.

BoxPlot

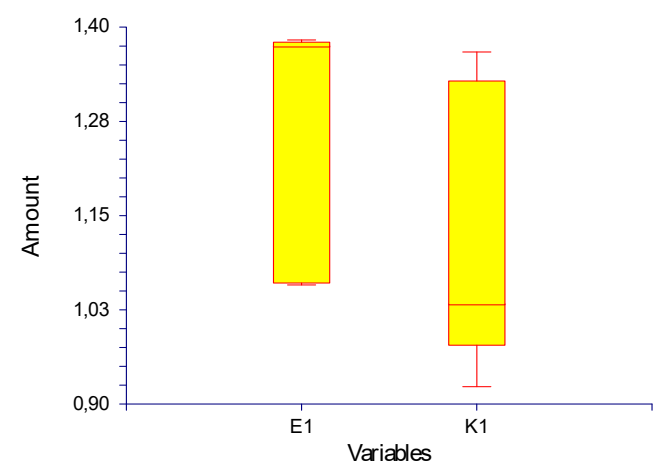

Fig.2 Box graph for index of interaction in the control and experimental teaching

\section{Conclusion}

The study presents a view on implementation of the touch devices in teaching. It is obvious that in analyzed lessons in the control and experimental teaching, pupils were very active (the mean index of interaction was higher than 1). In previous observations when we followed up the effect of interactive board and pedagogical communication and interaction, application of this technology led to higher index of interaction in the experimental teaching [6]. The mean index of interaction in the control teaching was smaller than 1. Technologies which become current didactic tools in schools were applied in both research observations. We are aware that the main effect on pedagogical interaction and communication is still in the hands of the teacher. It is the teacher on whom use of technologies depends, it means the way how pupils are activated. Pupils' activity could be 
suppressed even with quality technologies. It would be very interesting to find out how and if the ways of tablet application (tablet nests, use 1:1 - one tablet, one pupil or BYOD system) could influence pedagogical communication and interaction in lessons.

\section{References}

1. Benchmarking Access and Use of ICT in European Schools. [online]. Bonn: Empirica.[cit.2011-10-14].Dostupnyz:http://ec.europa.eu/information society/eeurope /i2010/ docs/studies/final_report_3.pdf. (2006)

2. Flanders, N. A., Analyzing teaching behavior. (1970)

3. Chráska, M. Metody pedagogického výzkumu. Praha: Grada.

4. IKT@Europe.edu. (2001). [online] Eurydice (český překlad Ústav pro informace ve vzdělávání, 2002). [cit. 2009-08-13]. Dostupné z: http://eacea.ec.europa.eu/ressources/eurydice/pdf/0_integral/020CS.pdf. (2007)

5. Knesplová, J., Škola hrou? S moderními technologiemi je to snadné [online]. Moderní vyučování, 2014. http://www.modernivyucovani.cz/skola-hrou-modernimitechnologiemi-je-snadne/(2014)

6. Maněnová, M., Vliv ICT na práci učitele 1. Stupně základní školy. Praha: Extrasystem Praha. (2013)

7. Marés, L., [online]. Tablets in Education. Relpe [cit. 2015-03-03]. http://www.relpe.org/wp-content/uploads/2012/04/Tablets-in-education.pdf (2012)

8. Roschelle, J., Tatar, D., Chaudhury, S. R., Dimitriadis, Y., Patton, C., \& DiGiano, C. Ink, improvisation, and interactive engagement: Learning with tablets. IEEE Computer, 40(9), 42-48 (2007)

9. STEPS, European Schoolnet [online]. [cit. 2009-09-10]. Dostupný z: http://www.eun.org/web. (2009)

10. Svatoš, T., Doležalová, J. Pedagogická interakce a komunikace pohledem vývoje kategoriálního systému. Hradec Králové: Gaudeamus. (2011) 